\title{
Role of sodium glucose cotransporter-2 inhibitors in type I diabetes mellitus
}

This article was published in the following Dove Press journal:

Diabetes, Metabolic Syndrome and Obesity:Targets and Therapy 2 May 2017

Number of times this article has been viewed

\section{Hala Ahmadieh' \\ Nisrine Ghazal ${ }^{2}$ \\ Sami T Azar}

'Faculty of Medicine, Clinical Sciences Department, Beirut Arab University, ${ }^{2}$ Department of Endocrinology and Metabolism, American University of Beirut, Beirut, Lebanon; ${ }^{3}$ Department of Internal Medicine, Division of Endocrinology, American University of Beirut, New York, NY, USA

Correspondence: Sami T Azar Department of Internal Medicine, Division of Endocrinology, American University of Beirut, 3 Dag Hammarskjold Plaza, 8th Floor, New York, NY 10017, USA

Tel + I 96I 3234250

Fax + I 9611744703

Email sazar@aub.edu.lb
Abstract: The burden of diabetes mellitus (DM) in general has been extensively increasing over the past few years. Selective sodium glucose cotransporter-2 (SGLT2) inhibitors were extensively studied in type $2 \mathrm{DM}$ and found to have sustained urinary glucose loss, improvement of glycemic control, in addition to their proven metabolic effects on weight, blood pressure, and cardiovascular benefits. Type 1 DM (T1D) patients clearly depend on insulin therapy, which till today fails to achieve the optimal glycemic control and metabolic targets that are needed to prevent risk of complications. New therapies are obviously needed as an adjunct to insulin therapy in order to try to achieve optimal control in T1D. Many oral diabetic medications have been tried in T1D patients as an adjunct to insulin treatment and have shown conflicting results. Adjunctive use of SGLT2 inhibitors in addition to insulin therapies in T1D was found to have the potential to improve glycemic control along with decrease in the insulin doses, as has been shown in certain animal and short-term human studies. Furthermore, larger well-randomized studies are needed to better evaluate their efficacy and safety in patients with T1D. Euglycemic diabetic ketoacidosis incidences were found to be increased among users of SGLT2 inhibitors, although the incidence remains very low. Recent beneficial effects of ketone body production and this shift in fuel energetics have been suggested based on the findings of protective cardiovascular benefits associated with one of the SGLT2 inhibitors.

Keywords: glycemic control, glycosylated hemoglobin, euglucemic diabetic ketoacidosis, oral antidiabetics

\section{Introduction}

Diabetes mellitus (DM) is a growing public health concern worldwide. The number of DM patients was estimated to be 382 million based on statistics in 2013, and this number is further expected to rise to 592 million by the year $2035 .{ }^{1} \mathrm{DM}$ is a chronic illness, characterized by high blood glucose level, resulting from impairments in insulin secretion, defects in insulin action, or both. DM is further classified into three main types: type 1 DM (T1D), type 2 DM (T2D), and gestational DM.

T1D occurs mainly due to autoimmune destruction of the insulin-producing pancreatic B-cells, leading to absolute insulin deficiency, where $>80 \%$ of those cells are being destroyed. ${ }^{2,3}$ Its incidence is increasing and it currently accounts for $5 \%-10 \%$ of all the cases of diabetes. More so, insulin therapy, the mainstay of therapy for T1D patients, proposes many challenges to physicians and patients.

Despite the clear beneficial advances over the past years in insulin formulation and its way of delivery in patients with T1D, continuous subcutaneous insulin infusion and continuous glucose monitoring (CGM) systems still fail to achieve the optimal 
metabolic targets that are needed to prevent risk of complications and are associated with weight gain and potential cardiovascular complications. ${ }^{4}$

Different oral antidiabetic drugs were tested in randomized controlled trials as adjunctive-to-insulin therapy. These include metformin, ${ }^{5,6}$ thiazolidinediones, ${ }^{7,8}$ alpha-glucosidase inhibitors, ${ }^{9,10}$ and incretin therapies, which include amylin analogs, ${ }^{11,12}$ dipeptydil peptidase-4 (DPP-4) inhibitors, ${ }^{13}$ and glucagon-like peptide-1 receptor agonists, ${ }^{14,15}$ with no consistent results with regard to insulin dose adjustment or HbA1c level. ${ }^{5-15}$

It is clear that there remains considerable room for trying to improve outcomes of treatment of patients with T1D. Exploration of new therapies is obviously needed as an adjunct to insulin in order to try to achieve optimal metabolic control in T1D patients.

Sodium glucose cotransporter-2 (SGLT2) inhibitors have been studied in T1D in animal and human studies and may be useful to improve glycemic control, as adjunctiveto-insulin therapy. This review highlights briefly the history of SGLT2 inhibitors as well as their use in T2D, focusing on their promising potential in T1D.

\section{History of SGLT inhibitors}

The history of SGLT2 inhibitors goes back to the late 1800s, when a compound called phlorizin, a natural phenolic O-glucoside, was found in the bark of apple trees and was put to use in multiple ways, most notably due to its physiological ability to cause glucosuria. Phlorizin was found to be a competitive nonselective inhibitor of both SGLT1 and SGLT2, had poor oral bioavailability, and was found to be toxic. This significantly limited its use later on. Moreover, clinical mutations of SGLT1 were found to be associated mainly with intestinal malabsorption of glucose and galactose and had little or no glucosuria effect. On the other hand, individuals with mutations in SGLT2 had no intestinal manifestations, but had persistent renal glucosuria, often in the range of $60-120 \mathrm{~g} /$ day. ${ }^{16}$

This led to extensive studies, which eventually led to the development of longer acting and more selective SGLT2 inhibitors, which were found to be effective antidiabetic agents and suitable for once-daily dosing without having harmful SGLT1 inhibiting effects. These medications were found to be effective as selective SGLT2 inhibitors, especially since diabetic patients have upregulation of the renal expression of SGLT2; therefore, the glucosuric and blood glucose lowering effect of SGLT2 inhibition was expected to be of great importance. ${ }^{17,18}$

\section{Efficacy of SGLT2 inhibitors in T2D}

SGLT2 inhibitors are oral antidiabetic agents currently approved for treatment of T2D. The first agent among these selective agents was dapagliflozin, launched by AstraZeneca and Bristol-Myers Squibb Company, and approved in the European Union in late 2012. ${ }^{19}$ This was later followed by canagliflozin, launched by Janssen Research and Development, and approved in 2013 by the US Food and Drug Administration (FDA). ${ }^{20}$ Empagliflozin, which was launched by Boehringer Ingelheim Pharmaceuticals, was later approved in 2014 by the US FDA. ${ }^{21}$

All these SGLT2 inhibitors led to sustained urinary glucose loss of $\sim 40-80 \mathrm{~g} /$ day and were found to be associated with good blood glucose lowering efficacy in T2D in addition to other beneficial effects such as lowering of body weight. ${ }^{17-19}$

SGLT2 inhibitors have clearly proven their efficacy in many different placebo-controlled trials in patients with T2D who were treated with diet and exercise, ${ }^{22,23}$ as well as add-ons to other glucose-lowering agents, such as metformin, ${ }^{24-27}$ sulfonylurea, ${ }^{28-31}$ pioglitazone, ${ }^{32-34}$ DPP-4 inhibitor, ${ }^{35,36}$ in triple oral therapies and in combination with insulin. ${ }^{37}$ They were found to be as active ${ }^{38-49}$ or even superior to other glucose lowering agents (sulfonylureas or sitagliptin). ${ }^{29,36}$ In a review article by Sheen, analysis of the various SGTL2 inhibitors randomized controlled trials demonstrated a very consistent effect on reduction in $\mathrm{HbA} 1 \mathrm{c}$ and body weight, whatever the background glucose lowering therapy and the nature of the SGLT2 inhibitor used. ${ }^{40}$

Moreover, SGLT2 inhibitors are characterized by their added benefits to address unmet clinical needs, such as weight loss, lipid lowering, and blood pressure control. ${ }^{42,43}$ They are generally well tolerated. The most prevalent adverse event associated with SGLT2 inhibitors consists of urinary and genital infections. ${ }^{6}$ Reversible increases in serum creatinine, prerenal in origin or secondary to tubular glomerular feedback mechanisms, have been reported. ${ }^{43}$ Low-density lipoprotein cholesterol concentrations also rise by $\sim 5 \%$, but are counterbalanced by increases in high-density lipoprotein cholesterol and reductions in triglyceride levels. ${ }^{40}$ Increase in hemoglobin concentrations and also hematocrit and hypoglycemia have been reported when SGLT2 inhibitors are combined with sulfonylureas or with insulin. ${ }^{43}$ Cases of euglycemic diabetic ketoacidosis (DKA) have been described, leading to issuing a US FDA warning in that matter. ${ }^{43}$ SGLT2 inhibitors can also increase urinary calcium excretion and/or serum phosphate levels. ${ }^{43}$ Finally, increase in fracture rates has been reported with canagliflozin. ${ }^{43}$ 


\section{Efficacy of SGLT2 inhibitors in TID patients}

As mentioned earlier, SGLT2 inhibitors are approved for T2D treatment, but there has been off-label use of these drugs in T1D patients despite the very low risk of euglycemic ketoacidosis cases reported. Some of these cases occurred in T1D patients, although the majority pertained to T2D. ${ }^{43}$

Adjunctive use of SGLT2 inhibitors in T1D was found to have potential to improve glycemic control, as has been shown in animal and short-term human studies (refer to Table 1 for a summary of human studies). ${ }^{46-50}$

An animal model study evaluated the effect of empagliflozin alone and in combination with insulin therapy on glucose control in animals with T1D and has suggested that this agent may be useful to improve glycemic control, as adjunct to insulin therapy, in animals with T1D. ${ }^{44}$ This former study was able to show that empagliflozin, when combined with low-dose insulin, showed similar glucose lowering efficacy, compared with high-dose insulin treatment alone.

Another animal study evaluated the potential efficacy of empagliflozin on recovering insulin pathways and improving pancreatic $\beta$-cell mass in streptozotocin-induced T1D mice, and again showed a beneficial effect on preserving $\beta$-cell regeneration, thus leading to improvement in blood glucose homeostasis. ${ }^{41}$ It was further hypothesized that this may actually be due to pancreatic $\beta$-cell protection from the toxic effect of high glucose and its induction of oxidative stress. ${ }^{45}$

A study on humans evaluated the efficacy and safety of empagliflozin, given at a dose of $25 \mathrm{mg}$ daily to 40 patients with T1D, for a total of 8 weeks. ${ }^{42}$ It concluded that empagliflozin did improve glycemic control and reduced hypoglycemic events, insulin doses, and weight in this patient population. ${ }^{46}$

The efficacy of remogliflozin in three different doses, 50,150 , and $500 \mathrm{mg}$, was studied on plasma glucose levels, after a $75 \mathrm{~g}$ oral glucose challenge, in 10 T1D patients, who were insulin pump users. ${ }^{47}$ Subjects continued to receive basal insulin and were then randomly allocated on separate days to receive prandial insulin, or placebo, or 1 of 3 doses of remogliflozin, before the oral glucose tolerance test. ${ }^{47}$ Compared with placebo, remogliflozin was associated with substantial improvements in the glucose profile over $10 \mathrm{~h}$, although mean glucose profiles were not as optimal as with prandial insulin. ${ }^{47}$

Dapagliflozin was evaluated in 70 adults with T1D who had uncontrolled $\mathrm{HbA} 1 \mathrm{c}$ at baseline, ranging between 7\% and $10 \%$, and who were receiving stable doses of insulin. ${ }^{44}$ Four dapagliflozin doses $(1,2.5,5$, or $10 \mathrm{mg})$ were tried and compared with placebo over a period of 2 weeks. Dapagliflozin had dose-related reductions in $24 \mathrm{~h}$ glucose monitoring and in insulin dosing, in addition to improvement in the overall glycemic variability, an emerging predictor of cardiovascular complications nowadays. Canagliflozin was also assessed in 351 adults with uncontrolled T1D, with a baseline $\mathrm{HbA} 1 \mathrm{c}$ range between $7.0 \%$ and $9.0 \%$, as an add-on treatment to insulin in an 18-week, double-blinded study. ${ }^{48}$ Canagliflozin in its 2 doses, 100 and $300 \mathrm{mg}$, was compared with placebo in these patients who were already on multiple daily insulin injections or continuous subcutaneous insulin infusion. The study demonstrated that more patients had $\mathrm{HbA} 1 \mathrm{c}$ reduction of $>0.4 \%$ with canagliflozin 100 and 300 $\mathrm{mg}$ versus placebo at the end of the study $(36.9 \%$ and $41.4 \%$ vs $14.5 \%$, respectively; $P<0.001) .{ }^{49}$ Canagliflozin did not lead to an increase in body weight or hypoglycemia rates. ${ }^{49}$ However, an increased incidence of ketone-related adverse events was noted $(5.1 \%, 9.4 \%$ vs $0 \%)$, with canagliflozin 100 and $300 \mathrm{mg}$ when compared with placebo. ${ }^{49}$

Sotagliflozin, a dual SGLT1 and 2 inhibitor, was assessed as an additional therapy to insulin in 33 patients with T1D, over a period of 29 days in a randomized, double-blinded trial. There was a significant reduction in total daily bolus insulin dose by $32.0 \%$ in the sotagliflozin group compared with $6.4 \%$ in the placebo group, which was accompanied by a significant reduction in the mean daily glucose level assessed by CGM of $148.8 \mathrm{mg} / \mathrm{dL}$ in the sotagliflozin group compared with $170.3 \mathrm{mg} / \mathrm{dL}$ in the placebo group. ${ }^{46}$ Body weight decreased significantly in the sotagliflozin group (1.7 $\mathrm{kg}$ ), while the placebo group had $0.5 \mathrm{~kg}$ gain..$^{50}$

Moreover, SGLT2 inhibitors in T1D may have renal protective effects as they tend to lower intra-glomerular pressure, and this has recently been demonstrated with empagliflozin in patients with T1D. ${ }^{47,51}$

Despite the above mentioned studies which pointed toward the beneficial effects of SGLT2 inhibitors on dose reduction and glucose control in addition to insulin therapy in T1D patients, larger randomized controlled trials are needed in order to better assess their efficacy.

\section{Mechanisms by which SGLT2 inhibitors therapy would provide clinical benefit as adjunct to insulin in TID}

Studies in mice and humans have consistently shown that chronic high glucose levels would increase B-cell apoptosis and cell death, consequently resulting in abnormally decreased insulin levels in both T1D and T2D. In T1D specifically, it is mostly cytokine-induced destruction of the 
Table I Summary of human studies on the use of SGLT2 inhibitors in TID patients

\begin{tabular}{|c|c|c|c|c|c|}
\hline $\begin{array}{l}\text { Reference of study } \\
\text { and trial type }\end{array}$ & Subjects & Characteristics of patients & Drug name & $\begin{array}{l}\text { Drug } \\
\text { dose }\end{array}$ & Results \\
\hline $\begin{array}{l}\text { Perkins et } \text { al }^{46} \\
\text { Open-label proof of } \\
\text { concept trial }\end{array}$ & $\begin{array}{l}40 \text { adults with } \\
\text { TID on insulin } \\
\text { therapy }\end{array}$ & $\begin{array}{l}50 \% \text { males, mean age was } \\
24.3 \pm 5 . \mathrm{I} \text { years, and had } \\
\mathrm{I} 7 . \mathrm{I} \pm 7 . \mathrm{I} \text { years diabetes } \\
\text { duration and } \mathrm{BMI} 24.5 \pm 3.2 \mathrm{~kg} / \\
\mathrm{m}^{2} \text { with an } \mathrm{HbAlc} \text { of } 8.0 \pm 0.9 \%\end{array}$ & $\begin{array}{l}\text { Empagliflozin vs placebo as } \\
\text { an adjunctive to insulin for } \\
\text { a total period of } 8 \text { weeks }\end{array}$ & $\begin{array}{l}25 \mathrm{mg} \\
\text { daily }\end{array}$ & $\begin{array}{l}\text { Improvement in } \\
\text { glycemic control, insulin } \\
\text { doses, and weight }\end{array}$ \\
\hline $\begin{array}{l}\text { Mudaliar et al }{ }^{47} \\
\text { Single-center, } \\
\text { randomized, } \\
\text { double-blinded, } \\
\text { placebo-controlled trial }\end{array}$ & $\begin{array}{l}10 \text { adults with } \\
\text { TID managed } \\
\text { with continuous } \\
\text { subcutaneous } \\
\text { insulin }\end{array}$ & Not available & $\begin{array}{l}\text { RE, placebo, prandial } \\
\text { insulin, as an adjunctive to } \\
\text { insulin. } \\
\text { Each subject participated } \\
\text { in } 5 \text { treatment periods } \\
\text { separated by } 5-35 \text { days }\end{array}$ & $\begin{array}{l}50,150, \\
\text { and } 500 \\
\mathrm{mg}\end{array}$ & $\begin{array}{l}\text { RE significantly reduced } \\
\text { the rise in plasma } \\
\text { glucose concentration after } \\
\text { oral glucose. } \\
\text { Similar adverse events in all } \\
\text { groups }\end{array}$ \\
\hline $\begin{array}{l}\text { Henry et al } \\
\text { Randomized, } \\
\text { double-blinded, } \\
\text { placebo-controlled } \\
\text { pilot study }\end{array}$ & $\begin{array}{l}70 \text { adults } \\
\text { with TID on } \\
\text { stable doses of } \\
\text { insulin (HbAlc } \\
7 \%-10 \%)\end{array}$ & $\begin{array}{l}61.5 \% \text { males, mean age } \\
\text { was } 35.3 \pm \mathrm{I} 2.9 \text { years, } \\
\text { and had } 16.2 \pm 9.7 \text { years } \\
\text { diabetes duration and BMI } \\
25.3 \pm 3 \mathrm{~kg} / \mathrm{m}^{2} \text { with an } \mathrm{HbAlc} \text { of } \\
8.75 \pm 0.92 \%\end{array}$ & $\begin{array}{l}\text { Dapagliflozin or placebo } \\
\text { as an adjunctive to stable } \\
\text { doses of insulin for a } \\
\text { period of } 7 \text { days }\end{array}$ & $\begin{array}{l}2.5,5 \text {, or } \\
10 \mathrm{mg}\end{array}$ & $\begin{array}{l}\text { Within the dapagliflozin } \\
\text { groups, there was an } \\
\text { observed increase in urinary } \\
\text { glucose excretion and dose- } \\
\text { related reductions in } 24 \mathrm{~h} \\
\text { glucose, glycemic variability, } \\
\text { and insulin dose }\end{array}$ \\
\hline $\begin{array}{l}\text { Henry et } \text { al }^{49} \\
\text { A double-blind, phase } \\
2 \text {, randomized study }\end{array}$ & $\begin{array}{l}35 \mathrm{I} \text { adults } \\
\text { with TID on } \\
\text { insulin (HbAIc } \\
7.0 \%-9.0 \%)\end{array}$ & $\begin{array}{l}63 \% \text { males, mean age was } \\
42 \pm \mathrm{II} .9 \text { years, and had } 23.3 \pm \mathrm{II} \\
\text { years diabetes duration and } \\
\mathrm{BMI} 28 \pm 3.6 \mathrm{~kg} / \mathrm{m}^{2} \text { with an } \\
\mathrm{HbAlc} \text { in } \mathrm{mmol} / \mathrm{mol} \text { of } 63 \pm 6.6\end{array}$ & $\begin{array}{l}\text { Canagliflozin or placebo as } \\
\text { an adjunctive to multiple } \\
\text { daily insulin injections or } \\
\text { continuous subcutaneous } \\
\text { insulin infusion over a } \\
\text { period of } 18 \text { weeks }\end{array}$ & $\begin{array}{l}100 \mathrm{or} \\
300 \mathrm{mg}\end{array}$ & $\begin{array}{l}\text { More patients had both } \\
\mathrm{HbAl} \text { c reduction } \geq 0.4 \% \\
\text { and no increase in body } \\
\text { weight with canagliflozin } \\
100 \text { and } 300 \mathrm{mg} \text { vs placebo } \\
\text { with similar incidence of } \\
\text { hypoglycemia. } \\
\text { Diabetic ketoacidosis } \\
\text { was seen with canagliflozin } \\
100 \text { and } 300 \text { mg vs placebo } \\
\text { (4.3\%, } 6.0 \%, 0 \% \text {, respectively) }\end{array}$ \\
\hline $\begin{array}{l}\text { Sands et al }{ }^{50} \\
\text { A randomized, } \\
\text { multicenter, } \\
\text { placebo-controlled, } \\
\text { double-blind trial }\end{array}$ & $\begin{array}{l}33 \text { patients with } \\
\text { TID on insulin } \\
\text { therapy }\end{array}$ & $\begin{array}{l}47 \% \text { males in placebo group } \\
\text { vs } 50 \% \text { in sotagliflozin group, } \\
\text { mean age was } 34 \text { years for } \\
\text { placebo vs } 45.5 \text { years for } \\
\text { sotagliflozin group. Patients } \\
\text { had mean diabetes duration } \\
\text { of I } 8.5 \text { years in placebo } \\
\text { group and } 16.8 \text { years for } \\
\text { sotagliflozin group. Mean BMI } \\
26.2 \pm 3 \mathrm{~kg} / \mathrm{m}^{2} \text { for placebo } \\
\text { group and } 27.1 \pm 3.1 \mathrm{~kg} / \mathrm{m}^{2} \text { for } \\
\text { sotagliflozin group. HbAIc } \\
\text { in mmol/mol } 62.8 \pm 5.6 \text { for } \\
\text { placebo group and } 63.3 \pm 6 \text { for } \\
\text { sotagliflozin group }\end{array}$ & $\begin{array}{l}\text { Sotagliflozin or placebo as } \\
\text { an adjunctive to previous } \\
\text { insulin delivery regimen } \\
\text { for a period of } 29 \text { days }\end{array}$ & $400 \mathrm{mg}$ & $\begin{array}{l}\text { Sotagliflozin decreased } \\
\text { total daily bolus insulin use, } \\
\text { lowered mean daily glucose } \\
\text { measured by continuous } \\
\text { glucose monitoring, and } \\
\text { patients had more time in } \\
\text { the target glycemic range. } \\
\text { Body weight also decreased } \\
(1.7 \mathrm{~kg}) \text { with sotagliflozin } \\
\text { treatment }\end{array}$ \\
\hline
\end{tabular}

Abbreviations: TID, type I diabetes mellitus; SGLT2, sodium glucose cotransporter-2; BMI, body mass index; RE, remogliflozin etabonate.

pancreatic B-cells. ${ }^{52}$ This appreciation of the importance of pancreatic $\beta$-cells in the pathogenesis of both T1D and T2D has led researchers to try to find ways to improve glucose homeostasis by preserving the function of these important cell types. ${ }^{53}$ Studies were able to show that SGLT2 inhibitors have the ability to lead to B-cell regeneration.

A study in diabetic mice models suggested that SGLT2 inhibition preserved islet mass, through decreased glucose-induced B-cell toxicity, and improved pancreatic B-cell functioning, where the frequency of cell death was calculated and assessed, and was shown that it significantly decreased with the drug. ${ }^{54}$ This was again confirmed in another study carried out in streptozotocin-induced T1D rats in an insulin-independent manner, where empagliflozin was shown to recover insulin pathways by improving pancreatic $\beta$-cell mass. ${ }^{55}$ 
Canagliflozin, 100 and $300 \mathrm{mg}$ doses, in humans was also shown to be capable of causing improvements in B-cell function with a resulting increase in fasting insulin secretion. ${ }^{56}$ This $\beta$-cell preservation was found to occur through an insulin-independent mechanism.

\section{Euglucemic DKA and SGLT2 inhibitors}

Although adverse events of SGLT2 inhibitors in T1D patients are similar to those in T2D, the risk of euglycemic DKA, especially after the US FDA warning, is worth mentioning. ${ }^{57}$ In fact, SGLT2 inhibitors are known to reduce the glucose available for energy utilization. Therefore, in the event of any extra demand for glucose, the SGLT2-inhibited body may not be able to maintain its homeostasis, leading to a ketogenic metabolic pathway. ${ }^{57}$ The alteration of insulin to glucagon ratio also plays a role in the pathogenesis of euglycemic DKA. ${ }^{58}$ The subsequent relative insulinopenia will manifest as ketonuria when challenged with stress, and high glucagon levels are associated with nausea, which may precipitate or worsen loss of appetite..$^{58}$

This has led the US FDA to issue warnings about this increased risk of euglycemic DKA associated with SGLT2 inhibitors. ${ }^{59}$ The US FDA warning occurred after the reporting, in the FDA Adverse Event Reporting System database, of 20 clinical cases of euglycemic DKA, necessitating hospitalization, among SGLT2 inhibitors users, from the period between March 2013 and June 2014. There is currently an ongoing review, initiated by European Medicines Agency, trying to evaluate the risk of euglycemic DKA among T2D patients, utilizing either dapagliflozin, canagliflozin or empagliflozin. ${ }^{60}$

It is worth mentioning that recent studies have suggested that this increase in ketone bodies is not always as deleterious as it may seem but may have some potential protective effects on the heart. This speculation was brought about after the noted beneficial cardiovascular effect found with SGLT2 inhibitors. As for the analysis of this beneficial cardiovascular effect, there have been many speculations, among which are diuretic and hemodynamic effects, due to the reduction in blood pressure and the decrease in extracellular volume.

A new interesting speculation has been introduced and this has suggested that this continued loss of urinary glucose and calories, that occurs with SGLT2 inhibitors, would lead to an accelerated starvation situation, with an increase in glucose reabsorption and endogenous glucose production, partly related to an increase in glucagon and a decrease in insulin levels, with an increased dependence on fat oxidation at the expense of glucose oxidation, which would then lead to an increase in free fatty acids and ketone bodies production.

Ketone bodies may have had a protective effect on the heart especially when the heart consumes and extracts them more efficiently compared with glucose and fatty acids, and thus may lead to an increase in myocardial contractility/renal work efficiency after this shift in the fuel utilization away from lipids and glucose, toward ketone bodies. ${ }^{61,62}$

Thus, the renal and cardiovascular benefit may be due to the shift in myocardial and renal fuel metabolism, which is found to occur with a rapid onset and is sustained in duration, which would explain this early noted improvement in cardiac and renal outcomes in these patients. ${ }^{63,64}$

These small beneficial changes in energetics can translate into large differences in efficiency over weeks to months. Good benefits in the heart would translate into kidney benefits as well and vice versa.

Detailed physiologic and imaging studies need to be performed in order to better understand the mechanisms behind these cardiovascular and renal benefits.

\section{Conclusion}

It is clear that there remains considerable room for trying to improve control and outcomes of T1D patients. New therapies are obviously needed, as complementary to insulin, with the aim of achieving optimal glycemic and metabolic control in patients with T1D. The beneficial effects of SGLT2 inhibitors on dose reduction and glucose control were assessed and tended to be consistently beneficial, but larger studies are needed to reach in-depth conclusions with regard to their use in patients with T1D especially given the concern of euglycemic DKA. Detailed physiologic and imaging studies need to be done in order to better understand the mechanisms behind these cardiovascular and renal benefits noted with SGLT2 inhibitors.

\section{Disclosure}

The authors report no conflicts of interest in this work.

\section{References}

1. American Diabetes Association. Standards of medical care in diabetes-2013. Diabetes Care. 2013;35:S11-S63.

2. Gorsuch A, Spencer K, Lister J, et al. Evidence for a long prediabetic period in type 1 (insulin-dependent) diabetes mellitus. Lancet. 1981; 2(8260-8261):1363-1365.

3. Knip M, Siljander H. Autoimmune mechanisms in type 1 diabetes. Autoimmunity Rev. 2008;7(7):550-557.

4. Kilpatrick ES, Rigby AS, Atkin SL. Insulin resistance, the metabolic syndrome, and complication risk in type 1 diabetes: "double diabetes" in the Diabetes Control and Complications Trial. Diabetes Care. 2007;30: $707-771$. 
5. George P, McCrimmon RJ. Potential role of non-insulin adjunct therapy in type 1 diabetes. Diabetic Med. 2013;30:179-188.

6. Vella S, Buetow L, Royle P, Livingstone S, Colhoun HM, Petrie JR. The use of metformin in type 1 diabetes: a systematic review of efficacy. Diabetologia. 2010;53(5):809-820.

7. Bhat R, Bhansali A, Bhadada S, Sialy R. Effect of pioglitazone therapy in lean type 1 diabetes mellitus. Diabetes Res Clin Pract. 2007;78:349-354.

8. Stone M, Walker J, Chisholm D, et al. The addition of rosiglitazone to insulin in adolescents with type 1 diabetes and poor glycaemic control: a randomized-controlled trial. Pediatr Diabetes. 2008;9(4 Pt 1):326-334.

9. Rabasa-Lhoret R, Burelle Y, Ducros F, et al. Use of an alpha-glucosidase inhibitor to maintain glucose homoeostasis during postprandial exercise in intensively treated type 1 diabetic subjects. Diabet Med. 2001;18(9):739-744.

10. Nagai E, Katsuno T, Miyagawa J, et al. Effects of miglitol in combination with intensive insulin therapy on blood glucose control with special reference to incretin responses in type 1 diabetes mellitus. Endocr $J$. 2011;58:869-877.

11. Whitehouse F, Kruger D, Fineman M, et al. A randomized study and open-label extension evaluating the long-term efficacy of pramlintide as an adjunct to insulin therapy in type 1 diabetes. Diabetes Care. 2002; 25:724-730

12. Ratner R, Whitehouse F, Fineman MS, et al. Adjunctive therapy with pramlintide lowers $\mathrm{HbA} 1 \mathrm{C}$ without concomitant weight gain and increased risk of severe hypoglycemia in patients with type 1 diabetes approaching glycemic targets. Exp Clin Endocrinol Diabetes. 2005;113:199-204.

13. Garg SK, Moser EG, Bode BW, et al. Effect of sitagliptin on postprandial glucagon and GLP-1 levels in patients with type 1 diabetes: Investigator-initiated, double-blind, randomized, placebo-controlled trial. Endocr Pract. 2013;19:19-28.

14. Kielgast U, Krarup T, Holst JJ, Madsbad S. Four weeks of treatment with liraglutide reduces insulin dose without loss of glycemic control in type 1 diabetic patients with and without residual beta-cell function. Diabetes Care. 2011;34:1463-1468.

15. Polsky S, Ellis SL. Obesity, insulin resistance, and type 1 diabetes mellitus. Curr Opin Endocrinol Diabetes Obes. 2015;22(4):277-282.

16. Vick H, Diedrich DF, Baumann K. Reevaluation of renal tubular glucose transport inhibition by phlorizin analogs. Am J Physiol. 1973;224(3):552-557.

17. Vallon V, Thomson SC. Renal function in diabetic disease models: the tubular system in the pathophysiology of the diabetic kidney. Annu Rev Physiol. 2012;74:351-375.

18. Washburn WN, Poucher SM. Differentiating sodium-glucose cotransporter-2 inhibitors in development for the treatment of type 2 diabetes mellitus. Expert Opin Investig Drugs. 2013;22:463-486.

19. FORXIGA ${ }^{\text {TM }}$ (dapagliflozin) now approved in European Union for treatment of type 2 diabetes. November 2012. Available from: https:// www.astrazeneca.com/media-centre/press-releases/2012/FORXIGAdapagliflozin-now-approved-in-European-Union-for-treatment-of-type2-diabetes-14112012. Accessed November 14, 2012.

20. FDA approves Invokana to treat type 2 diabetes. March 2013. Available from: http://www.fda.gov/NewsEvents/Newsroom/PressAnnouncements/ucm345848.htm. Accessed November 14, 2012.

21. FDA approves Jardiance (empagliflozin) to treat type 2 diabetes. August 2014. Available from: https://www.drugs.com/newdrugs/fdaapproves-jardiance-empagliflozin-type-2-diabetes-4064.html. Accessed November 14, 2012.

22. Ferrannini E, Ramos SJ, Salsali A, Tang W, List JF. Dapagliflozin monotherapy in type 2 diabetic patients with inadequate glycemic control by diet and exercise: a randomized, double-blind, placebo-controlled, phase 3 trial. Diabetes Care. 2010;33(10):2217-2224.

23. Bailey CJ, Iqbal N, T'Joen C, List JF. Dapagliflozin monotherapy in drug-naive patients with diabetes: a randomized-controlled trial of low-dose range. Diabetes Obes Metab. 2012;14(10):951-959.

24. Kaku K, Kiyosue A, Inoue S, et al. Efficacy and safety of dapagliflozin monotherapy in Japanese patients with type 2 diabetes inadequately controlled by diet and exercise. Diabetes Obes Metab. 2014;16(11):1102-1110.
25. Bailey CJ, Gross JL, Pieters A, Bastien A, List JF. Effect of dapagliflozin in patients with type 2 diabetes who have inadequate glycaemic control with metformin: a randomised, double-blind, placebo controlled trial. Lancet. 2010;375(9733):2223-2233.

26. Henry RR, Murray AV, Marmolejo MH, Hennicken D, Ptaszynska A, List JF. Dapagliflozin, metformin XR, or both: initial pharmacotherapy for type 2 diabetes, a randomised controlled trial. Int J Clin Pract. 2012;66(5):446-456.

27. Rosenstock J, Seman LJ, Jelaska A, et al. Efficacy and safety of empagliflozin, a sodium glucose cotransporter 2 (SGLT2) inhibitor, as add-on to metformin in type 2 diabetes with mild hyperglycaemia. Diabetes Obes Metab. 2013;15(12):1154-1160.

28. Haring HU, Merker L, Seewaldt-Becker E, et al. Empagliflozin as add-on to metformin in patients with type 2 diabetes: a 24-week, randomized, double-blind, placebo-controlled trial. Diabetes Care. 2014;37(6):1650-1659.

29. Strojek K, Yoon KH, Hruba V, Elze M, Langkilde AM, Parikh S. Effect of dapagliflozin in patients with type 2 diabetes who have inadequate glycaemic control with glimepiride: a randomized, 24-week, double-blind, placebo-controlled trial. Diabetes Obes Metab. 2011;13(10):928-938.

30. Haring HU, Merker L, Seewaldt-Becker E, et al. Empagliflozin as addon to metformin plus sulfonylurea in patients with type 2 diabetes: a 24-week, randomized, double-blind, placebo-controlled trial. Diabetes Care. 2014;37:1480-1483.

31. Wilding J, Charpentier G, Hollander P, et al. Efficacy and safety of canagliflozin in patients with type 2 diabetes mellitus inadequately controlled with metformin and sulphonylurea: a randomised trial. Int $J$ Clin Pract. 2013;67(12):1267-1282.

32. Forst T, Guthrie R, Goldenberg R, et al. Efficacy and safety of canagliflozin over 52 weeks in patients with type 2 diabetes on background metformin and pioglitazone. Diabetes Obes Metab. 2014;16(5):467-477.

33. Rosenstock J, Vico M, Wei L, Salsali A, List JF. Effects of dapagliflozin, an SGLT2 inhibitor, on $\mathrm{HbA}(1 \mathrm{c})$, body weight, and hypoglycemia risk in patients with type 2 diabetes inadequately controlled on pioglitazone monotherapy. Diabetes Care. 2012;35(7):1473-1478.

34. Kovacs C, Seshiah V, Swallow R, et al. Empagliflozin improves glycaemic and weight control as add-on therapy to pioglitazone or pioglitazone plus metformin in patients with type 2 diabetes: a 24-week, randomized, placebo-controlled trial. Diabetes Obes Metab. 2014;16(2):147-158.

35. Jabbour SA, Hardy E, Sugg J, et al. Dapagliflozin is effective as add-on therapy to sitagliptin with or without metformin: a 24-week, multicenter, randomized, double-blind, placebo-controlled study. Diabetes Care. 2014;37(3):740-750.

36. Roden M, Weng J, Eilbracht J, et al. Empagliflozin monotherapy in drug-nave patients with type 2 diabetes: a randomised, 24-week, double-blind, placebo-controlled, parallel group, trial with sitagliptin as active comparator. Lancet Diabetes Endocrinol. 2013;1(3):208-219.

37. Rosenstock J, Jelaska A, Frappin G, et al. Improved glucose control with weight loss, lower insulin doses, and no increased hypoglycemia with empagliflozin added to titrated multiple daily injections of insulin in obese inadequately controlled type 2 diabetes. Diabetes Care. 2014;37(7):1815-1823.

38. Liakos A, Karagiannis T, Athanasiadou E, et al. Efficacy and safety of empagliflozin for type 2 diabetes: a systematic review and meta-analysis. Diabetes Obes Metab. 2014;16(10):984-993.

39. Yang X, Lai D, Zhong X, Shen HP, Huang YL. Efficacy and safety of canagliflozin in subjects with type 2 diabetes: systematic review and meta-analysis. Eur J Clin Pharmacol. 2014;70(10):1149-1158.

40. Scheen A. Pharmacodynamics, efficacy and safety of sodium-glucose co-transporter type 2 (SGLT2) inhibitors for the treatment of type 2 diabetes mellitus. Drugs. 2015;75:33-59.

41. Lambers Heerspink HJ, de Zeeuw D, Wie L, Leslie B, List J. Dapagliflozin a glucose-regulating drug with diuretic properties in subjects with type 2 diabetes. Diabetes Obes Metab. 2013;15(9):853-862.

42. Majewski C, Bakris G. Blood pressure reduction: an added benefit of sodium-glucose cotransporter 2 inhibitors in patients with type 2 diabetes. Diabetes Care. 2015;48:429-430. 
43. Reddy R, Inzucchi S. SGLT2 inhibitors in the management of type 2 diabetes. Endocrine. 2016;53(2):364-372.

44. Luippold G, Klein T, Mark M, Grempler R. Empagliflozin, a novel potent and selective SGLT-2 inhibitor, improves glycaemic control alone and in combination with insulin in streptozotocin-induced diabetic rats, a model of type 1 diabetes mellitus. Diabetes Obes Metab. 2012;14:601.

45. Cheng S, Chen L, Li S, Mayoux E, Leung PS. The effects of empagliflozin, an SGLT2 inhibitor, on pancreatic $\beta$-cell mass and glucose homeostasis in type 1 diabetes. PLoS One. 2016;11(1):e0147391.

46. Perkins B, Cherney D, Partridge H, et al. Sodium-glucose cotransporter 2 inhibition and glycemic control in type 1 diabetes: results of an 8-week open-label proof-of-concept trial. Diabetes Care. 2014;37: 1480-1483.

47. Mudaliar S, Armstrong D, Mavian A, et al. Remogliflozin etabonate, a selective inhibitor of the sodium-glucose transporter 2, improves serum glucose profiles in type 1 diabetes. Diabetes Care. 2012;35:2198-2200.

48. Henry R, Rosenstock J, Edelman S, et al. Exploring the potential of the SGLT2 inhibitor dapagliflozin in type 1 diabetes: a randomized, double-blind, placebo-controlled pilot study. Diabetes Care. 2015;38(3):412-419.

49. Henry R, Thakkar P, Tong C, Polidori D, Alba M. Efficacy and safety of canagliflozin, a sodium glucose cotransporter 2 inhibitor, as add-on to insulin in patients with type 1 diabetes. Diabetes Care. 2015;38(12):2258-2265.

50. Sands A, Zambrowicz B, Rosenstock J, et al. Sotagliflozin, a dual SGLT1 and SGLT2 inhibitor, as adjunct therapy to insulin in type 1 diabetes. Diabetes Care. 2015;38(7):1181-11188

51. Cherney DZ, Perkins BA, Soleymanlou N, et al. Renal hemodynamic effect of sodium-glucose cotransporter 2 inhibition in patients with type 1 diabetes mellitus. Circulation. 2014;129(5):587-597.

52. Cnop M, Welsh N, Jonas J-C, Jörns A, Lenzen S, Eizirik DL. Mechanisms of pancreatic-cell death in type 1 and type 2 diabetes many differences, few similarities. Diabetes. 2005;54(2):S97-S107.

53. Vetere A, Choudhary A, Burns SM, Wagner BK. Targeting the pancreatic $\beta$-cell to treat diabetes. Nat Rev Drug Discov. 2014;13: 278-289.
54. Jurczak MJ, Lee HY, Birkenfeld AL, et al. SGLT2 deletion improves glucose homeostasis and preserves pancreatic B-cell function. Diabetes. 2011;60(3):890-898.

55. Cheng ST, Chen L, Li SYT, Mayoux E, Leung PS. The effects of empagliflozin, an SGLT2 inhibitor, on pancreatic $\beta$-cell mass and glucose homeostasis in type 1 diabetes. PLoS One. 2016;11(1):e0147391.

56. Stenlöf K, Cefalu WT, Kim KA, et al. Efficacy and safety of canagliflozin monotherapy in subjects with type 2 diabetes mellitus inadequately controlled with diet and exercise. Diabetes Obes Metab. 2013; 15(4):372-382.

57. Kalra S, Sahay R, Gupta Y. Sodium glucose transporter 2 (SGLT2) inhibition and ketogenesis. Indian J Endocrinol Metab. 2015;19(4):524.

58. Kalra S, Gupta Y, Patil S. Sodium-glucose cotransporter-2 inhibition and the insulin: glucagon ratio: unexplored dimensions. Indian J Endocrinol Metab. 2015;19:426-429.

59. U.S. Food and Drug Administration. Drug Safety Communication: FDA warns that SGLT2 inhibitors for diabetes may result in a serious condition of too much acid in the blood [Internet], 15 May 2015. Available from: http://www.fda.gov/ downloads/Drugs/DrugSafety/UCM446954. pdf. Accessed June 22, 2015.

60. European Medicines Agency. Review of diabetes medicines called SGLT2 inhibitors started: risk of diabetic ketoacidosis to be examined [Internet], 12 June 2015. Available from: http://www.ema.europa.eu/docs/ en_GB/document_library/Referrals_document/SGLT2_inhibitors_20/ Procedure_started/WC500187926.pdf. Accessed June 22, 2015.

61. Abdul-Ghani M, Del Prato S, Chilton R, DeFronzo RA. SGLT2 inhibitors and cardiovascular risk: lessons learned from the EMPA-REG OUTCOME study. Diabetes Care. 2016;39(5):717-725.

62. Mudaliar S, Alloju S, Henry RR. Can a shift in fuel energetics explain the beneficial cardiorenal outcomes in the EMPA-REG OUTCOME study? A unifying hypothesis. Diabetes Care. 2016;39(7):1115-1122.

63. Tomaselli GF, Zipes DP. What causes sudden death in heart failure? Circ Res. 2004;95:754-763.

64. Cahill GF Jr, Veech RL. Ketoacids? Good medicine? Trans Am Clin Climatol Assoc. 2003;114:149-161.

Diabetes, Metabolic Syndrome and Obesity: Targets and Therapy

\section{Publish your work in this journal}

Diabetes, Metabolic Syndrome and Obesity: Targets and Therapy is an international, peer-reviewed open-access journal committed to the rapid publication of the latest laboratory and clinical findings in the fields of diabetes, metabolic syndrome and obesity research Original research, review, case reports, hypothesis formation, expert
Dovepress

opinion and commentaries are all considered for publication. The manuscript management system is completely online and includes a very quick and fair peer-review system, which is all easy to use. Visit $\mathrm{http}: / / \mathrm{www}$. dovepress.com/testimonials.php to read real quotes from published authors. 